http://ejournal.universitasmahendradatta.ac.id/index.php/satyagraha

\title{
PENGARUH KOMPENSASI FINANSIAL DAN KOPENSASI NON FINANSIAL TERHADAP KEPUASAN KERJA KARYAWAN
}

\author{
Jaenab \\ Prodi manajemen, Sekolah tinggi Ilmu Ekonomi (STIE) Bima \\ Jl. Wolter Mongisidi Kompleks Tolobali Kota Bima \\ Email: jaenab.stiebima@gmail.com
}

\begin{abstract}
This study aims to explain the effect of variable financial compensation and nonfinancial compensation on employee job satisfaction simultaneously and partially. This study uses an explanatory research method with a quantitative approach. The population in this study were 36 employees and the research sample used was a saturated sample of 36 employees at PT. Kawi brilliant Bima. The analysis used is multiple linear regression. The results of the study simultaneously show that financial compensation and non-financial compensation have a significant effect on employee job satisfaction. Sig value. The F which is obtained is 0,000. The results of the study partially show that financial compensation has no significant effect on employee job satisfaction with a sig value. $t$ of -283 . The result of the research is partially known that non-financial compensation has a significant effect on employee job satisfaction with a sig.t value of 5,563.
\end{abstract}

Keywords: financial compensation, non-financial compensation and job satisfaction.

\begin{abstract}
Abstrak-Penelitian ini bertujuan untuk menjelaskan pengaruh antara variabel kompensasi finansial dan kompensasi non finansial terhadap kepuasan kerja karyawan secara simultan dan parsial. Penelitian ini menggunakan metode explanatory research dengan pendekatan kuantitatif. Populasi dalam penelitian ini sebanyak 36 orang pegawai dan adapun Sampel penelitian yang di gunakan adalah sampel jenuh yakni 36 orang karyawan pada PT. Kawi cemerlang Bima. Analisis yang digunakan adalah regresi linier berganda, Hasil penelitian secara simultan diketahui bahwa kompensasi finansial dan kompensasi non finansial berpengaruh signifikan terhadap kepuasan kerja karyawan. Nilai sig. F yang di peroleh sebesar 0,000. Hasil penelitian secara parsial menunjukkan kompensasi finansial tidak berpengaruh sacara signifikan terhadap kepuasan kerja karyawan dengan nilai sig. t sebesar .283. Hasil penelitian secara parsial diketahui bahwa kompensasi non finansial berpengaruh signifikan terhadap kepuasan kerja karyawan dengan nilai sig.t sebesar 5.563.
\end{abstract}

Kata kunci: Kompensasi finansial, Kompensasi non finansial dan Kepuasan kerja. 


\section{PENDAHULUAN}

Persaingan bisnis yang semakin maju sekarang ini, menuntut perusahaan untuk memperoleh Sumber daya manusia yang berkualitas, ini di lakukan karena semakin besarnya industri tetapi sumber daya manusia yang memiliki keahlian dan pengetahuan yang berkualitas semakin sedikit dan terbatas. Perusahaan menargetkan untuk selalu berkembang dengan baik secara financial maupun non finansial. peran sangat penting untuk di kelola karena walaupun berlimpahnya sumber daya alam dan tersedianya modal yang cukup apabila semua hal tersebut tidak akan berjalan dengan baik, Peningkatan kepuasan kerja karyawan perlu di lakukan untuk memaksimalkan peranan tenaga kerja di dalam perusahaan. Semakin meningkatkatnya kepuasan kerja karyawan akan mendorong para karyawan untuk menciptakan inovasi baru dan meningkatkan jumlah barang atau jasa.

Kompensasi (Remunirasi) merupakan imbalan jasa yang di berikan perusahaan kepada tenaga kerja karena telah memberikan sumbangan tenaga dan pikiran demi kemajuan dan kontinuitas perusahaan dalam rangka mencapai tujuan yang telah di tetapkan baik dalam jangka pendek maupun jangka panjang (Siswanto dalam Farla, W., dkk., 2019). Kompensasi merupakan suatu pilihan yang tepat untuk mengatasi masalah ketenagakerjaan bagi kebanyakan organisasi. Kesalahan dalam menetapkan kompensasi dapat membuat perusahaan mengalami kerugian, karyawan yang ada akan merasa tidak puas, beberapa pegawai akan cenderung mengelapkan uang perusahaan dan sangat mungkin untuk meninggalkan perusahaan. Pemberian kompensasi erat kaitanya dengan kepuasan kerja ketika kompensasi yang terima karyawan sesuai dengan harapan maka karyawan akan merasa puas dan termotivasi untuk bekerja.

Kepuasan kerja dapat didefinisikan sebagai suatu keadaan emosional yang menyenangkan atau tidak menyenangkan dimana Kepuasan kerja juga memiliki hubungan yang erat dengan kinerja pegawai. Menurut Hasibuan (dalam Nugrahanti, P., dkk, 2019) Kepuasan kerja adalah sikap emosional yang menyenangkan dan mencintai pekerjaanya. Kepuasan kerja biasanya merupakan permasalahan yang serius yang perlu di perhatikan oleh perusahaan karena kepuasan kerja tidak akan meningkat dengan sendirinya tanpa adanya peran dari pihak perusahaan dan kemauan dari karyawan itu sendiri. Permasalahan kepuasan karyawan sering terjadi di perusahaan yang lalai dalam memperhatikan lingkungan dimana pegawai melaksanakan tugasnya misalnya hubungan rekan kerja tidak sehat, hubungan dengan pimpinan yang kurang harmonis, suasana kerja dan hal-hal lain yang dapat mempengaruhi kemampuan seseorang dalam menjalankan tugasnya.

PT. Kawi cemerlang merupakan distributor barang produk wings keseluruh kota dan kabupaten Bima. Adapun kegiatan rutin para karyawan menyalurkan barangbarang prodak wings terdiri dari deterjen daia, mie sedaap, minuman ale-ale, pewangi, pengharum dll. Adapun sumber daya manusia nya terdiri dari bagian sopir, sales, admin, gudang dan helper. Permasalahan yang sering di keluhkan oleh karyawan sedikitnya gaji pokok yang menyebabkan banyak kebutuhan karyawan yang tidak bisa di penuhi untuk keperluan sehari-hari, tidak adanya uang pesangon yang di dapatkan dari perusahaan, tidak ada lagi bonus bagi karyawan yang melebihan target penjualan sehingga ketidak sesuaian imbalan yang di terima itu menyebabkan rendahnya kepuasan kerja seperti ada beberapa karyawan tidak masuk kerja, ada pemotongan gaji apabila tidak masuk kerja, rendahnya semangat kebersamaan tim kerja.

Berdasarkan uraian latar belakang permasalahan yang dapat di telaah: 1) apakah kompensasi finansial berpengaruh signifikan terhadap kepuasan kerja. 2) apakah kompensasi 
http://ejournal.universitasmahendradatta.ac.id/index.php/satyagraha

non finansial berpengaruh signifikan terhadap kepuasan kerja. 3) apakah kompensasi finansial dan kompensasi non finansial berpengaruh signifikan terhadap kepuasan kerja.

Adapun tujuan penelitian ini 1) untuk mengetahui apakah kompensasi finansial berpengaruh signifikan terhadap kepuasan kerja. 2) untuk mengetahuiapakah kompensasi non finansial berpengaruh signifikan terhadap kepuasan kerja. 3) untuk mengetahui apakah kompensasi finansial dan kompensasi non finansial berpengaruh signifikan terhadap kepuasan kerja.

Kompensasi adalah semua pendapatan yang berbentuk uang, barang langsung atau tidak langsung yang di terima karyawan sebagai imbalan atas jasa yang di berika kepada perusahaan. Sistem pemberian kompensasi dalam perusahaan harus di sesuaikan denga tujuan dan strategi perusahaan. Perusahaan harus menyeimbangkan biaya kompensasi untuk menjamin daya saing organisasi dan memberikan penghargaan yang adil kepada para karyawan atas pengetahuan, keterampilan dan kinerjanya. Menurut Fatei, et al (Priyatono, 2019) ketika penghargaan dan pengakuan yang efektif di terapkan dalam sebuah perusahaan dan lingkungan kerja yang menguntungkan dapat memotivasi karyawan untuk unggul dalam kenerja mereka. Di perkuat oleh Sultana, (Priyatono, 2019). Kompensasi merupakan penghargaan atau imbalan dala bentuk uang atau non uang yang disediakan oleh perusahaan atas waktu, keahlian, keterampialan dan upaya yang di lakukan oleh karyawan dalam memenuhi persyaratan pekerjaan yang bertujusn untuk mencapai tujuan bisnis.

Menurut Rivai (dalam Nugrahanti, P., dkk, 2019) . Kompensasi merupakan sesuatu yang terima karyawan sebagai pengganti kontribusi jasa mereka pada perusahaan. Sedangkan menurut Swanto, (2011) Kompensasi ditinjau dari sudut individu karyawan adalah segala sesuatu yang di terima karyawan sebagai balas jasa atas kontribusi tenaga dan pikiran yang telah di sumbangkan pada organisasi.

Kompensasi finansial langsung adalah kompensasi yang sistem pembayarannya secara langsung diberikan kepada karyawan dalam bentuk gaji pokok (base payment): Gaji, Upah dan kompensasi variabel yang meliputi insentif atau bonus (Nugrahanti, P., dkk, 2019)

Kompensasi finansial tidak langsung adalah kompensasi yang di bayarkan dalam bentuk uang tetapi sistem pembayarannya di lakukan setelah jatuh tempo atau pada peristiwa-peristiwa yang terjadi di masa akan datang yang telah di sepakati sebelumnya. Kompensasi tidak langsung juga dengam tunjangan seperti asuransi, asuransi kesehatan dari perusahaan, tunjangan hari raya (THR) dan dana pensiun. Menurut Martoyo, (dalam Nugrahanti, P., dkk, 2019) Kompensasi non finansial terdiri dari pekerjaan itu sendiri seperti tugas yang menarik, tantangan dalam bekerja dan tanggung jawab terhadap pekerjaan dan lingkungan kerja dimana orang itu bekerja seperti lingkungan kerja yang nyaman dan rekan kerja yang mendukung.

Wibowo, (dalam Aristya, dkk.,2019) Kepuasan kerja adalah tingkat perasaan senang seseorang sebagai penilaian positif terhadap pekerjaannya dan lingkungan tempat pekerjaanya. Kepuasan kerja adalah suatu sikap umum individu terhadap pekerjaan seseorang yang menunjukkan perbedaan antara jumlah penghargaan yang di terima dan jumlah yang mereka yakini seharusnya mereka terima. (Robbins dalam Wibowo, 2011).

Menurut luthans (dalam Nugrahanti, P., dkk, 2019) pengkuran kepuasan kerja ada 5, antara lain: 1) Pekerjaan itu sendiri, dalam hal ini dimana perusahaan menarik tantangan dalam pekerjaan, tantangan dalam pekerjaan, tanggung jawab terhadap pekerjaan menghubungkan antara kepribadian dengan kepuasan kerja. 2) Gaji, pemberian gaji yang sesuai dengan kontribusi karyawan, ketepatan 
http://ejournal.universitasmahendradatta.ac.id/index.php/satyagraha

waktu dalam pembayaran gaji dan sistem pemberian gaji di dalam perusahaan merupakan salah satu faktor penentu kepusana kerja karyawan. 3) Promosi, kesempatan untuk maju dalam organisasi merupakan salah satu penentu kepuasan kerja. 4) Pengawasan, kemampuan penyelia untuk memberikan bantuan tehnik dan dukungan perilaku serta hubungan yang baik akan menjadi faktor penentu kepuasan kerja karyawan dalam perusahaan. 5) Rekan kerja, rekan kerja yang kooperatif merupakan sumber kepuasan kerja yang paling sederhana pada karyawan secara individu terutama rekan kerja yang bertindak sebagai sumber dukungan, kenyamanan dan nasihat.

\section{Hipotesis}

H1: Kompensasi finansial berpengaruh signifikan terhadap kepuasan kerja.

$\mathrm{H} 2$ : Kompensasi non finansial berpengaruh signifikan terhadap kepuasan kerja.

H3: Kompensasi finansial dan kompensasi non finansial berpengaruh signifikan terhadap kepuasan kerja.

\section{METODE PENELITIAN}

Penelitian ini merupakan penjelasan (explanatory research). Menurut Sugiyono, (2011) metode explanatory research merupakan metode penelitian yang beraksud menjelaskan kedudukan variable-variabel yang di teliti serta pengaruh antar variable dengan variable lain. Populasi pada penelitian ini adalah seluruh karyawan yang ada pada PT. Kawi cemerlang yang berjumlah 36 orang, sedangkan Sampel yang digunakan yaitu sampel jenuh dengan mengambil seluruh karyawan sebanyak 36 orang karyawan sebagai responden. Skala pengukuran data dalam penelitian ini adalah skala likert sebagai alat untuk mengukur sikap, pendapat dan persepsi seseorang atau kelompok orang tentang fenomena sosial. Dalam melakukan penelitian terhadap variabel-veariabel yang akan diuji pada setiap jawaban akan di beri skor 1-5
(Sugiyono, 2011). Tehnik pengumpulan data dengan menggunakan observasi, wawancara kemudian penyebarkan kuesioner.

Pengujian instrumen menggunakan uji validitas dan reliabilitas sedangkan uji asumsi klasik dengan uji multikoloniaeritas, uji autokorelasi, uji heteroskedastisitas dan uji normalitas. Setelah semua item pengukuran valid dan reliabel data kemudian di analisis dengan menggunakan regresi linier berganda uji $\mathrm{t}$, uji $\mathrm{F}$, koefisien determinasi dengan menggunakan SPSS versi 20.

\section{HASIL PENELITIAN DAN PEMBAHASAN Uji validitas \\ Tabel 1. Hasil uji validitas}

\begin{tabular}{|c|c|c|c|c|}
\hline r. Hitung & r. Hitung & r. Hitung & $\begin{array}{c}\text { Tab } \\
\text { el }\end{array}$ & Ket. \\
\hline Variabl X1 & Variabl X2 & Variabl Y & & \\
\hline (X1.1) 0,671 & $(\mathrm{X} 2.1) 0,701$ & (Y1) 0,623 &, 30 & Valid \\
\hline (X1.2) 0,602 & (X2.2) 0,465 & (Y2) 0,504 &, 30 & Valid \\
\hline (X1.3) 0,770 & $(\mathrm{X} 2.3) 0,581$ & (Y3) 0,696 &, 30 & Valid \\
\hline (X1.4) 0,478 & (X2.4) 0,574 & (Y4) 0,388 & ,30 & Valid \\
\hline (X1.5) 0,634 & $(\mathrm{X} 2.5) 0,701$ & (Y5) 0,592 &, 30 & Valid \\
\hline (X1.6) 0,576 & $(\mathrm{X} 2.6) 0,465$ & (Y6) 0,530 &, 30 & Valid \\
\hline (X1.7) 0,792 & $(X 2.7) 0,353$ & (Y7) 0,742 &, 30 & Valid \\
\hline (X1.8) 0,671 & (X2.8) 0,553 & (Y8) 0,495 &, 30 & Valid \\
\hline (X1.9) 0,602 & (X2.9) 0,581 & (Y9) 0,444 & ,30 & Valid \\
\hline (X1.10) 0,770 & (X2.10) 0,574 & (Y10) 0,504 &, 30 & Valid \\
\hline (X1.11) 0,478 & (X2.11) 0,701 & (Y11) 0,376 &, 30 & Valid \\
\hline \multirow[t]{2}{*}{ (X1.12) 0,457} & $(\mathrm{X} 2.12) 0,465$ & (Y12) 0,742 &, 30 & Valid \\
\hline & & (Y13) 0,530 &, 30 & Valid \\
\hline
\end{tabular}

Sumber data diolah, 2020.

Berdasarkan tabel 1. Dapat diketahui bahwa semua koefisien korelasi dari indikator indikator variabel penelitian yang telah diujikan memiliki nilai lebih besar dari 0,30 (r $>0,30$ dan $\mathrm{Sig}<0,05$. Hal ini dapat menunjukkan bahwa semua indikator-indikator pada penelitian ini dapat dinyatakan valid. 
Jurnal Satyagraha

Vol.04, No.01, Pebruari 2021 - Agustus 2021

ISSN : 2620-6358

http://ejournal.universitasmahendradatta.ac.id/index.php/satyagraha

Uji Reliabilitas

Tabel 2. Hasil Uji Reliabilitas

\begin{tabular}{clll}
\hline No & \multicolumn{1}{c}{ Variabel } & $\begin{array}{c}\text { Cronbach's } \\
\text { Alpha }\end{array}$ & Ket. \\
\hline 1 & Kompensasi finansial & 0,956 & Reliabel \\
2 & Kompensasi non finansial & 0,968 & Reliabel \\
3 & Kepuasan kerja & 0,924 & Reliabel \\
\hline
\end{tabular}

Sumber: Hasil olahan SPSS, 2020

Hasil uji bahwa masing-masing nilai Cronbach's alpha pada tiap instrument penelitian lebih besar dari 0,6 (Cronbach's alpha $>0,6)$. Dengan demikian hasil tersebut menunjukkan bahwa semua instrument terbukti reliabel, sehingga dapat digunakan untuk melakukan penelitian

\section{Analisis Regresi Linier Berganda}

Analisis regresi ini digunakan untuk menghitung besarnya pengaruh antar variable bebas yaitu kompensasi finansial (X1) dan kompensasi non finansial (X2) terhadap variable terikat yaitu kepuasan kerja karyawan (Y). Hasil pengujian analisis regresi berganda di jelaskan sebagai berikut:

Tabel 3. Hasil Uji Regresi Linier Berganda

Unstandardized

Coefficients

\begin{tabular}{lcccc} 
Model & B & \multicolumn{2}{l}{ Std. Error t } & Sig. \\
\hline (Constant) & 31.915 & 4.726 & 6.752 & 000 \\
$\begin{array}{l}\text { Kompensasi } \\
\text { finansial }\end{array}$ & -.021 & .075 & -.283 & 779 \\
$\begin{array}{l}\text { Kompensasi } \\
\text { finansial }\end{array}$ & non & & & \\
& & .105 & 5.563 & 000 \\
\hline
\end{tabular}

sumber : Hasil olahan SPSS, 2020

Berdasarkan hasil di atas dapat di rumuskan bentuk persamaan linier berganda yaitu $\mathrm{Y}+31,915+-0,021 \mathrm{X} 1+0,582 \mathrm{X} 2+\mathrm{e}$. Dapat dilihat bahwa nilai beta (Beta) masingmasing variabel menunjukkan nilai positif, ini berarti semakin tinggi variabel kompensasi non finansial dapat mempengaruhi kepuasan kerja karyawan, sedangkan nilai kompensasi finansial bernilai negatif artinya akan menurunkan kepuasan kerja karyawan.

\section{Analisis Koefisien Determinasi}

Tabel 4. Hasil Uji Determinasi $\left(\mathrm{R}^{2}\right)$

\begin{tabular}{|c|c|c|c|c|}
\hline Model & $\begin{array}{l}\mathrm{R} \\
\text { Square }\end{array}$ & $\begin{array}{l}\text { AdjustedR } \\
\text { Square }\end{array}$ & $\begin{array}{l}\text { Std. Error o } \\
\text { the Estimate }\end{array}$ & $\begin{array}{l}\text { fDurbin- } \\
\text { Watson }\end{array}$ \\
\hline & ${ }^{\mathrm{a}} 490$ & .459 & 3.236 & 1.634 \\
\hline
\end{tabular}

Dari diatas dapat diketahui bahwa koefisien determinasi (Adjusted $R$ Square) yang di peroleh sebesar 0,581 Hal ini menujukan bahwa variabel kompensasi finansial dan kompensasi non finansial hanya mempengaruhi sebesar $45 \%$ terhadap kepuasan kerja karyawan, sedangakan sisanya 55\% dipengaruhi oleh variabel lain yang tidak di teliti dalam penelitian ini. Semakin besar nilai Adjusted $R$ Square, maka semakin besar (kuat) hubungan antara variable independen terhadap variable dependen. Nilai koefisien $\mathrm{R}$ pada tabel 2 sebesar 0,700 menunjukkan hubungan antara variable independen dengan variable dependen karena memiliki nilai koefisien korelasi di tas 0,05 . Dalam tabel 2 tersebut juga terdapat standar error of the estimate (SEE) sebasar 3.236. semakin kecil nilai SEE akan membuat model regresi semakin tepat dalam tepat dalam memperprediksi variabel dependen danagn kepuasan kerja.

Uji persial atau ( uji t )

Tabel 5. Hasil Uji Regresi Linier Berganda

\begin{tabular}{lcccc}
\hline \multicolumn{5}{c}{ Unstandardized } \\
Coefficients \\
\multicolumn{1}{c}{ Model } & $\mathrm{B}$ & \multicolumn{1}{c}{ Std. Error } & $\mathrm{t}$ & \multicolumn{1}{c}{ Sig. } \\
\hline (Constant) & 31.915 & 4.726 & 6.752 & .000 \\
$\begin{array}{l}\text { Kompensasi } \\
\text { finansial }\end{array}$ & -.021 & .075 & -.283 & .779 \\
$\begin{array}{l}\text { Kompensasi } \\
\text { non finansial }\end{array}$ & .582 & .105 & 5.563 & .000 \\
\hline
\end{tabular}

Sumber : Hasil olahan SPSS, 2020 
Jurnal Satyagraha

Vol.04, No.01, Pebruari 2021 - Agustus 2021

ISSN : 2620-6358

http://ejournal.universitasmahendradatta.ac.id/index.php/satyagraha PEMBAHASAN

Berdasrkan tabel 8 bahwa hasil olahan data SPSS versi 20 diatas diperoleh hasil sebagai berikut:

1. Variabel X1 (kompensasi finansial) memiliki nilai $\mathrm{t}$ hitung sebesar $-0,283$ dengan signifikansi sebesar 0,779 . Atau sig. $<5 \%(0,779<0,05)$, maka Ho di terima H1 ditolak dan dapat disimpulkan bahwa secara parsial variabel kompensasi finansial tidak berpengaruh positif dan signifikan terhadap kepuasan kerja karyawan.

2. Variabel X2 (kompensasi non finansial) memiliki nilai t- hitung sebesar 5.563 dengan signifikansi sebesar 0,000. Atau sig. $<5 \%(0,000>0,05)$, maka Ho di tolak dan $\mathrm{H} 2$ diterima maka dapat disimpulkan bahwa secara parsial variabel kompensasi non finansial berpengaruh positif dan signifikan terhadap kepuasan kerja karyawan

Uji Simultan ( uji F )

Tabel 6. Uji Simultan

ANOVA $^{\mathrm{a}}$

\begin{tabular}{ccclc}
\hline Model & \multicolumn{2}{c}{$\begin{array}{l}\text { Sum of } \\
\text { Squares }\end{array}$ f } & $\begin{array}{l}\text { Mean } \\
\text { Square }\end{array}$ & sig. \\
\hline 1 & Regression & 331.918 & 165.959 & $5.845 \quad 000^{\mathrm{b}}$ \\
Residual & $345.637_{3}$ & 10.474 & & \\
Total & $677.556_{5}$ & & & \\
& & & & \\
\hline
\end{tabular}

Sumber : Hasil olahan SPSS, 2020

Pada hasil perhitungan Uji F didapatkan

angka signifikan sebesar 0,000 . Nilai signifikan $<0,05$ ini menunjukkan adanya pengaruh antara variabel bebas dan terikat. Nilai $0,000<0,05$ sehingga dapat dikatakan model tersebut linear atau ada pengaruh yang signifikan variabel kompensasi finansial dan kompensasi non finansial terhadap kepuasan kerja karyawan.

\section{Pengaruh kompensasi finansial} terhadap kepuasan kerja karyawan

Hasil statistik uji t untuk variabel diperoleh nilai t- hitung sebesar $0,-283$ dengan nilai t- tabel sebesar 2,042 $(0,-283<2,042)$ dengan nilai signifikansi sebesar 0,000 lebih kecil dari $0,05(0,000<0,05)$, maka hipotesis (H1) yang menyatakan bahwa kompensasi finansial berpengaruh signifikan terhadap kepuasan kerja karyawan "Ditolak". Hal ini memberikan makna bahwa gaji, uang lembur, tunjungan hari raya, tunjungan keluarga dan insentif atau bonus) terhadap kepuasan kerja karyawan.

Hasil Penelitian ini tidak sejalan dengan penelitian Oktavia, D., 2015) yang mengatakan bahwa kompensasi finansial berpengaruh positif dan signifikan terhadap kepuasan kerja karyawan di Akor Global.

\section{Pengaruh kompensasi non finansial} terhadap kepuasan kerja karyawan

Hasil statistik uji $\mathrm{t}$ untuk variabel diperoleh nilai t- hitung sebesar 5.563 dengan nilai t- tabel sebesar 2,042 $(5.563>2,042)$ dengan nilai signifikansi sebesar 0,000 lebih kecil dari $0,05(0,000<0,05)$, maka hipotesis (H2) yang menyatakan bahwa kompensasi non finansial berpengaruh signifikan terhadap kepuasan kerja karyawan "Diterima". Hal ini memberikan makna bahwa kesempatan pendidikan, kesempatan pelatihan, cuti kerja, kenaikan pangkat, dan fasilitas transportasi) yang diberikan (meliputi rekan kerja, pengawasan, peluang promosi dan pekerjaan itu sendiri. Artinya kompensasi non finansial berpengaruh lebih besar terhadap kepuasan kerjan. Hasil penelitian ini sejalan dengan penelitian Oktavia, D., 2015, yang menyebutkan bahwa Kompensasi non finansial berpengaruh signifikan terhadap kepuasan kerja karyawan. 
Jurnal Satyagraha

Vol.04, No.01, Pebruari 2021 - Agustus 2021

ISSN : 2620-6358

http://ejournal.universitasmahendradatta.ac.id/index.php/satyagraha

Pengaruh kompensasi finansial dan permasalahan yang di hadapi. Diharapkan kompensasi non finansial terhadap kepada PT. Kawi cemerlang dapat kepuasan kerja karyawan

Hasil pengujian hipotesis (H3)

meningkatkan perhatiannya terhadap

Diketahui bahwa kopensasi finansial dan finansial demi meningkatkan kepuasan kerja kompensasi non finansial berpengaruh karyawan.

signifikan terhadap kepuasan kerja karyawan terferivikasi karena mempunyai nilai Fhitung sebasar 15.845 yang mana lebih besar dari pada sebesar Ftabel 2,9223. Dengan demikian hipotesis (H3) yang menyatakan bahwa kompensasi finansial dan kompensasi non finansial berpengaruh signifikan terhadap kepuasan kerja “ Diterima" Penelitian ini sejalan dengan hasil penelitian Nugraheni, dkk., (2020) dan Oktavia, D., 2015) yang menyatakan bahwa kompensasi finansial dan kompensasi non finansial secara bersama-sama berpengaruh signifikan terhadap kepuasan kerja karyawan.

\section{KESIMPULAN DAN SARAN}

Berdasarkan hasil penelitian ini, ditemukan adanya 1) Kompensasi finansial tidak berpengaruh signifikan terhadap kepuasan kerja karyawan. 2) Kompensasi non finansial berpengaruh signifikan terhadap Kepuasan kerja karyawan. 3) Kompensasi finansial dan Kompensasi non finansial berpengaruh signifikan terhadap kepuasan kerja karyawan.

\section{Saran}

Saran yang dapat di simpulkan dari penelitian ini hendaknya kompensasi non finansial PT. Kawi cemerlang dapat di tingkatkan kesempatan pendidikan, kesempatan pelatihan, cuti kerja, kenaikan pangkat memiliki nilai paling kecil. Penelitian ini masih memiliki beberapa keterbatasan waktu yang singkat dan karyawan distributor yang sulit di temui yang jauh menyebabkan kurangnya variasi dan rincian tindakan maupun data penelitian yang di peroleh PT. Kawi cemerlang. Penelitian ini masih secara umum, sehingga masih kurang melakukan spesifikasi

\section{Daftar pustaka}

Arisya, I, Astuti, E \& Sulistyo, M., (2019). Pengaruh kompensasi finansial dan non finansial terhadap motivasi kerja dan kepuasan kerja karyawan (Studi pada karyawan wisma SIER PT Surabaya industrial Estate Rungkut). Jurnal administrasi bisnis (JAB) Vol. 77, No. 1. Hal. 30-39.

Farla.W, Yuliansyah, M. Diah, Supardi. A., (2019). Pengaruh kompensasi finansial dan kompensasi non finansial terhadap komitmen karyawan. Jurnal manajemen dan kewirausahaan \& Kewirausahaan Universitas sriwijaya Palembang. ISSN Prin 2301-9093, ISSN Online: 2540-8259. Vol. 7, No. 1. Hal 78 - 85.

Kusumaningtyas dan Suddin, (2012). Pengaruh Kompensasi terhadap kepuasan kerja karyawan Bank Mega dengan motivasi kerja sebagai variabel moderasi. Jurnal manajemen sumber daya manusia Vol. 6 . No. 2 .hal. 95-105.

Nugrahanti, dkk, (2016). Pengaruh kompensasi finansial dan non finansial terhadap kepuasan kerja dan prestasi kerja karyawan (Studi pada karyawan PT. Telkom Indonesia witel jatim selatan Malang. Jurnal administrasi Bisnis (JAB) Vol. 40 No. 1. Hal. 67-75.

Nugraheni,A., (2020). Pengaruh kopensasi finansial dan kompensasi non finansial terhadap kepuaasan kerja karyawan (Studi pada dosen dan staf fakultas bahasa dan 
http://ejournal.universitasmahendradatta.ac.id/index.php/satyagraha

seni UKSW salatiga). Jurnal ekobis

Dewantara. Vol. 3. No. 1. Hal 11-19.

Oktavia, D.,(2015). Pengaruh kompensasi finansial dan non finansial terhadap kepuasan kerja karyawan akor global. AGORA Vol. 3, No. 1. Hal. 56-61.

Priyatono, M., (2019). Pengaruh kompensasi finansial dan kompensasi non finansial terhadap kupuasan kerja karyawan mesastila hotel resorts. Jurnal Media wisata, ISSN 1693-5969. Vol 17. No. 1

Swanto, Bambang, 2011. Manajemen sumber daya manusia. Malang: UB press.

Sugiyono, (2011). Statistik untuk penelitian. Bandung: Alphabeta. 